\title{
ON FIRST-STAGE LARVAL RESISTANCE \\ UNDER CONTROLLED CONDITIONS OF THREE SPECIES OF NEMATODES OF THE FAMILY PROTOSTRONG YLIDAE \\ LEIPER, 1926
}

\author{
A. REgUERA-FEO*, F. A. ROJO-VAZQUEZ* and M. CORDERO-DEL-CAMPILLO**
}

\begin{abstract}
SUMMARY. A study was made on the survival of the first larval-stage of three species of the Family Protostrongylidae (Cystocaulus ocreatus, Muellerius capillaris and Neostrongylus linearis). At every temperature $\left(5,12,20,26\right.$ and $\left.36^{\circ} \mathrm{C}\right)$ and humidity $(100,70$ and $30 \%)$ combinations, the species which needed the least time to reach the pre-established $(50,75$ and $95 \%)$ mortality rates was Neostrongylus linearis. In all cases Muellerius capillaris was the species needing the longest time to reach the same mortality percentages (rates). The direct relationship between the survival capacity of each species and their relative abundance in the grazing zone of the sheep used as a source of larvae studied is also discussed. The comparison of our results with those of other authors is made on the basis of an adaptive relationship between the species of parasites studied and their definitive hosts.
\end{abstract}

\section{Sur la résistance des larves du premier stade de trois espèces de Nématodes de la famille des Protostrongylidae Leiper, 1926 en conditions contrôlées.}

RÉSUMÉ. La survie des premiers stades larvaires de trois espèces de Nématodes de la famille des Protostrongylidae (Cystocaulus ocrealus. Muellerius capillaris et Neostrongylus linearis) a été étudiée quels que soient la température $\left(5,12,20,26\right.$, et $\left.36^{\circ} \mathrm{C}\right)$, et le taux d'hygrométrie $(30$, $70,100 \%$ utilisés, c'est l'espèce $N$. linearis qui atteint le plus rapidement les pourcentages de mortalité pré-établis, et l'espèce $M$. capillaris qui les atteint le plus lentement.

La relation trouvée entre la capacité de survie de chaque espèce et son abondance relative dans la zone de paturage utilisée par les ovins, est discutée. L'existence possible d'une adaptation entre les espèces de parasites étudiés et leurs hôtes définitifs est discutée en comparant nos résultats et ceux d'autres auteurs.

\section{Introduction}

As in the case of all poikilothermic animals, nematodes exhibit comparatively narrow thermal limits within which they are able to survive. According to Croll (1970) these limits lie between $5^{\circ}$ and $40^{\circ} \mathrm{C}$, while Wallace (1961) places them within the $10^{\circ}$ and $55^{\circ} \mathrm{C}$ range for most species of nematodes.

- Depto Patología infecciosa y parasitaria, Fac. Veterinaria, Madrid, España.

- Depto Patología infecciosa y parasitaria, Fac. Veterinaria, León, España.

Accepté le I 6 août 1985 . 
Studies on the first stage larvae of protostrongylids as a function of environmental factors, temperature and relative humidity were begun many years ago (Davtian, 1937 ; Pavlov, 1937) though most of the data collected comes from research mainly directed to elucidate the life cycle of these nematodes.

The purpose of this work was to determine the relationship between the survival capacity of Cystocaulus ocreatus, Muellerius capillaris and Neostrongylus linearis under controlled conditions of temperature and humidity and the abundance of these species in the grazing zones of two flocks of sheep previously used by one of us (Reguera-Feo, 1983) for epidemiological studies on lungworm infection in sheep.

\section{Materials and methods}

Series of " cultures " were prepared, starting out from the faeces of sheep with pure infections, kept in a continuous stable regimen, from flocks grazing in the province of León (Sapin).

Pure infection by C. ocreatus (Raillet and Henry, 1907) was found in a flock grazing in Puebla de Lillo and the infections by $M$. capillaris (Mueller, 1889) and $N$. linearis (Marotel, 1913) in Villacete.

In order to obtain first stage larvae of each species, the corresponding sheep was placed in a metabolic cage and after about $10 \mathrm{~h}$ the faeces destined for coproculture were collected. $90 \mathrm{~g}$ of such faeces, previously evaluated for larval content per gram by the Baermann method, were placed in an hermetically sealed glass recipient. The cultures were warmed in ovens at $5,12,20,26$ and $36^{\circ} \mathrm{C}$ in individual wells containing different glycerine and water concentrations for the purpose of obtaining relative humidities of 100,70 and $30 \%$.

From that moment onwards weekly counts were made of the number of live larvae in each $3 \mathrm{~g}$ of faeces until the result was negative over 2 consecutive weeks.

The criterion used to determine the vital activity parameters of the larvae was their migratory capacity. The number of larvae present in $3 \mathrm{~g}$ of faeces was plotted as larvae/g, referring to the original weight. The value found was later transformed into percentages with respect to the initial values in larvae/g in order to integrate the data of the different replicates of the same coproculture and to compare the results with those of other types, in the same and in other species.

Seven replicates were carried out for each temperature-humidity combination ; the values obtained were fitted, by the usual minimal squares method, to different kind of regression slopes, altering the scales of the Cartesian axis in each case (RegueraFeo et al., 1981).

The coprocultures of $C$. ocreatus at $36^{\circ} \mathrm{C}$ and 70 and $30 \%$ relative humidity could not be carried out owing to the death of the donor sheep by an infectious process (clamidiosis) before the experiments had been completed. 


\section{Results}

In each case, the most significant regression slope was chosen for use in the calculation of the number of days which had to elapse for the 3 species to reach a given percentage of mortality, under the conditions employed.

The species needing the least time to reach $50 \%$ mortality ( $f i g$. 1) was, in general, $N$. linearis ; the opposite (the longest time necessary to reach this mortality percentage) was $M$. capillaris, with a survival which was clearly greater at intermediate temperatures : 15-25 days at $12^{\circ} \mathrm{C}$ and $20^{\circ} \mathrm{C}$, respectively; about 10 days at $26^{\circ} \mathrm{C}$ and somewhat less at $5^{\circ} \mathrm{C}$.

The same situation was maintained in order to reach a $75 \%$ mortality rate (fig. 2) and the effect of relative humidity (the lower the humidity the shorter the time needed to reach the indicate level) in $M$. capillaris and $N$. linearis.

To reach a $95 \%$ mortality rate ( $f$ ig. 3 ), the number of days needed was seen to
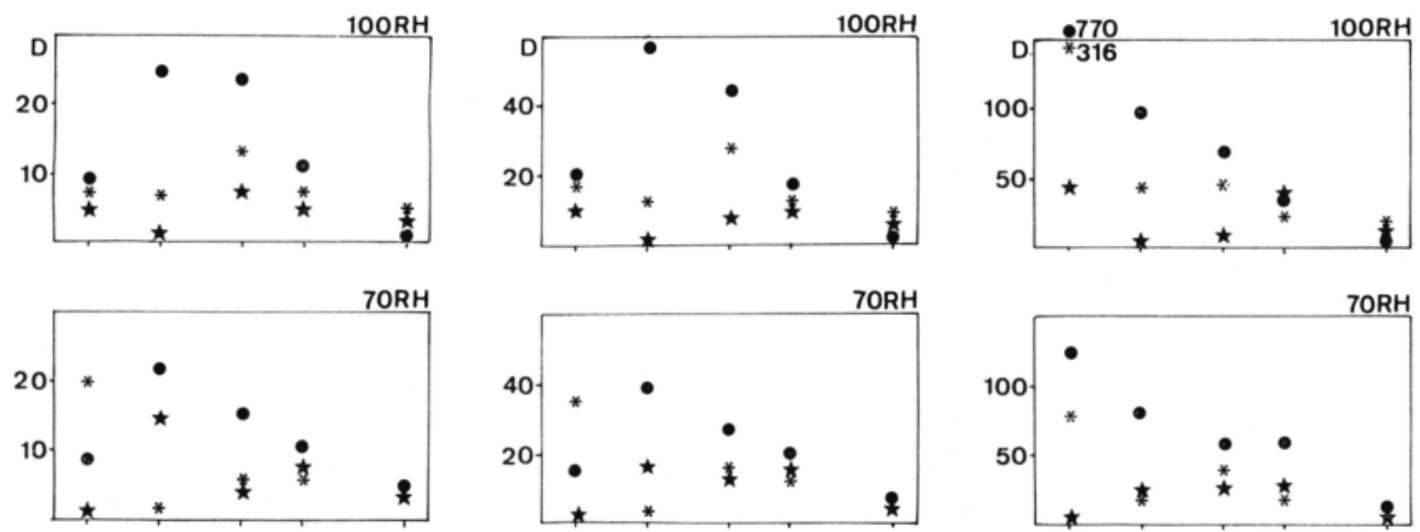

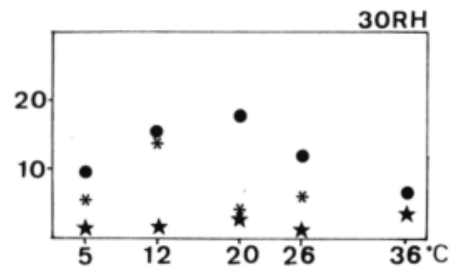

FIG. I.

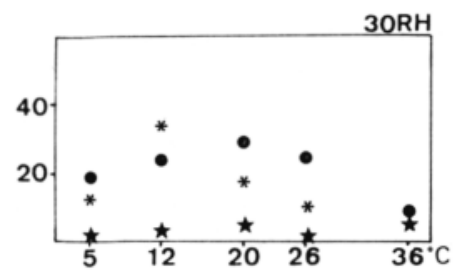

FIG. 2.

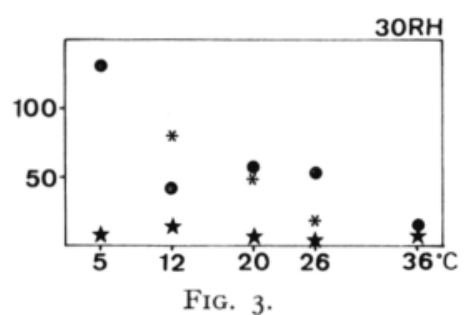

FIG. I. - Time taken for Cystocaulus ocveatus $\left({ }^{*}\right)$, Muellerius capillaris and Neostrongylus linearis $(\star)$ first-stage larvae to reach $50 \%$ mortality rate. $\mathrm{D}$, days ; $\mathrm{RH}$, relative humidity.

FIG. 2. - Time taken for Cystocaulus ocreatus (*), Muellerius capillaris (-) and Neostrongylus linearis $(\star)$ first-stage larvae to reach $75 \%$ mortality rate.

$\mathrm{D}$, days ; $\mathrm{RH}$, relative humidity.

FIG. 3. - Time taken for Cystocaulus ocreatus (*), Muellerius capillaris (•) and Neostrongylus linearis $(\star)$ first-stage larvae to reach $95 \%$ mortality rate. $\mathrm{D}$, days ; $\mathrm{RH}$, relative humidity. 
be inversely proportional to temperature, and relative humidity was not affecting the results in this case; as before, $M$. capillaris and $N$. linearis were the species which needed the most and the fewest days, respectively.

\section{Discussion}

According to Gerichter (1951), the optimal temperature for the activity of the first stage larvae of protostrongylids is $25-27^{\circ} \mathrm{C}$. These temperatures, together with a high relative humidity would favour activity and, therefore, considerable expenditure of energy leading to the consequent depletion of food reserves and later death. Contrariwise, according to Kassai (1958) these mean temperatures, in combination with a relative humidity of more than $90 \%$ would lead to a low mortality rate.

Our own data are more in agreement with those of this later author, particularly for the case of $M$. capillaris. We have observed in this species that humidity is inversely proportional to larval survival, particularly at mid-term, as Rose (1957) has also pointed out.

In the other two species studied, this relationship is not so well defined; indeed, in the case of $C$. ocreatus it is inverted over longer periods of time. These results are in agreement with those reported by Schanzel (1958) referring to C. ocreatus, who found a lower mortality rate at higher temperatures in dry faeces, though in these the initial survival rate was very reduced.

Of interest are the great differences between our data and those of Sattlerovà (1982) since, in our case, $N$. linearis was seen to be a very labile species compared to $M$. capillaris whereas according to Sattlerovà (ibid.) were dealing with larvae of $M$. tenuispiculatus Gebauer, 1932, a species present in the field area of this author, together with $M$. capillaris or, on the other hand, such differences could be the result of an adaptive relationship between eithe- Neostrongylus and Rupicapra, and between Muellerius and Ovis.

Reguera-Feo (1983), studying the epidemiology of sheep lungworm infection in the same areas from which the definitive donors hosts used in this work, found that $M$. capillaris and $N$. linearis were the most and the least abundant species, respectively. So it can be concluded that the resistance capacity of the species studied is directly related to the abundance of this nematodes in sheep from the area from which the donors sheep originate.

\section{REFERENGES}

Croll N. A. : The Behaviour of Nematodes. Their activity, senses and responses. Edward Arnold Publishers Ltd., London, I970.

Davtian E. A. : A study of the life-cycle of Synthetocaulus kochi Schulz, Orlov et Kutass, r933, the Iungworm of sheep and goat. Skrjabin Anniv. Vol., I937, pp. Io5-I 22.

Gerichter Ch. B. : Studies on the lung nematodes of sheep and goats in the Levant. Parasitology, I95I, $4 I$, I 66-I 83 .

Kassai T. : Vizsgálatok a juhok gócos tüdoférgességérol. VII resz. A juhok gócos tüdofergességenek járvárystana. Magyar Allatorvosok Lapja, 1958, 7 : 125-127. 
Pavlov P. : Recherches expérimentales sur le cycle évolutif de Synthetocaulus capillaris. Ann. Parasitol. Hum. Comp., I937, I , 500-503.

Reguera-Feo A. : Sobre la epizootiología de las protostrongilidosis ovinas en la provincia de León. Tesis doct. Fac. Biol. Léon, 1983, Léon.

Reguera-Feo A., Cordero-del-campillo M., y Rojo-Vazquez F. A. : Supervivencia de las larvas I de Neostrongylus linearis (Nematoda, Protostrongylidae) en condiciones controladas de humedad y temperatura. An. Fac. Vet. León, I981, 27, 109-I I8.

Rose J. H. : Observations on the bionomics of the free-living first stage larvae of the sheep lungworm Muellerius capillaris. $J$. Helminth., 1957, 31, I7-28.

SAtile Rova A. : The resistance of first stage larvae of Muellerius spp. and Neostrongylus linearis (from the faeces of chamois, Rupicaprar. tatrica) to different physical factors under laboratory and natural conditions. Helminthologia, I982, Ig, I5I-I60.

Schanzel H. : Plicnica Cystocaulus ocreatus Railliet et Henry, 1907, u ovcí v CSR. Sbornik Vysoké Skoly Zemedelské a Lesnicské v Brne. Rada B. Spisy, Fak. Vet., 1958, 6, 265-270.

Wallace H. R. : The bionomics of the free-living stages of zoo-parasite and phyto-parasite Nematodes - a critical survey. Helminth. Abstr., I961, 30, I-22. 